\title{
English language students' productive and receptive knowledge of collocations
}

\author{
Mirna Begagić \\ University of Zenica
}

\begin{abstract}
The importance of collocations in second language learning has been recognized in the past few decades. There have been numerous studies in L2 acquisition research that investigated how the knowledge and use of collocations at different levels of proficiency affect learners' communicative competence and language performance. Moreover, it seems important to mention that most of the studies investigating the collocational knowledge of students learning English as their L2, indicated students' poor performance (Fayez-Hussein 1990; Aghbar 1990; Bahns and Eldaw 1993; Stubbs 2002; Wray 2002; Nasselhauf 2005; Ozaki 2011). The aim of this paper is to explain the notion of collocation as well as its most common classification, and to point out the importance of its proper use for English language students who are native speakers of the Bosnian/Croatian/Serbian (BCS) language. Furthermore, this study examines the productive and receptive knowledge of lexical collocations in order to access students' collocational competence. The results indicate students' poor collocational knowledge. This can be due to the fact that collocations of the language students are learning are interfering with the collocations of their mother tongue, but also due to the way students are taught English (vocabulary negligence in comparison with grammar and unawareness of the importance of collocations in language learning).
\end{abstract}

Key words: collocation; collocational competence; receptive and productive collocations.

\section{Introduction}

\subsection{Collocations}

The term collocation was first introduced by Firth (1957). Firth's attempt to describe the meaning of a word at the collocational level was something completely new in that it looked at the meaning relations between lexical items from the level of syntagmatic relations, i.e. a word's ability to combine with other words. Most of the linguists interested in the topic still define collocation as the tendency of a lexical item to co-occur with one or more words (Halliday, McIntosh \& Strevens, 1964; Ridout \& Waldo-Clarke, 1970; Backlund 1973, 1976; Seaton, 1982; Crystal, 1985; Cruse, 1986; Sinclair, 1991; Zhang, 1993). Consider the following examples: 
(1) a. This heavy rain will probably cause flooding.

b. *This strong rain will probably cause flooding.

(2) a. She has a strong will to survive.

b. *She has a heavy will to survive.

Examples (1) and (2) indicate that nouns rain and will collocate with different adjectives - in (1a) rain choosing the adjective heavy, and in (2a) will choosing the adjective strong. The resulting combinations are grammatically correct and sound natural to native speakers. However, in $(1 \mathrm{~b})$ and $(2 \mathrm{~b})$ the combinations strong rain and heavy will are unacceptable ${ }^{1}$. They would be considered incorrect by native speakers, due to the fact that these are not natural collocations, and these combinations might have been influenced by the speaker's first language. A collocation that is acceptable in one language might not be acceptable in another (strong rain unacceptable in the English language, but its literal translation jaka kiša is acceptable and very frequent collocation in the BCS language).

\subsection{Grammatical and lexical collocations}

Although collocations can be classified in many different ways, the most common classification is the one into grammatical and lexical collocations. The former category consists of a noun, an adjective or a verb plus a preposition or a grammatical structure such as 'to + infinitive' or 'that-clause', e.g. by accident, to be afraid that... The latter category does not contain grammatical elements, but presents a combination of lexical items, i.e. nouns, adjectives, verbs and adverbs (Benson, Benson and Ilson, 1986).

According to The BBI Combinatory Dictionary of English there are 8 basic types of grammatical and 7 types of lexical collocations:

Grammatical collocations:

- G1=noun + preposition e.g. blockade against, apathy towards

- $\mathrm{G} 2=$ noun + to-infinitive e.g. He was a fool to do it.

- G3=noun + that-clause e.g. We reached an agreement that she would join our team.

- $\mathrm{G} 4=$ preposition + noun e.g. by accident, in agony

- G5=adjective + preposition e.g. fond of children, hungry for news

- $\mathrm{G} 6=$ adjective + to-infinitive e.g. it was necessary to work, it's nice to be here

\footnotetext{
${ }^{1}$ Example (1b) 'strong rain' is a less serious collocational error than example (2b) 'heavy will', but is still considered odd by native speakers, and should not be used.
} 
- $\mathrm{G} 7=$ adjective + that-clause e.g. she was afraid that she would fail

- G8=different patterns in English e.g. verb + to-infinitive (they began to speak), verb + bare infinitive (we must work) and other. ${ }^{2}$

Lexical collocations:

- $\quad \mathrm{L} 1=$ verb (which means creation/action) + noun/pronoun/prepositional phrase e.g. come to an agreement, launch a missile

- $\quad \mathrm{L} 2=$ verb (which means eradication/cancellation) + noun e.g. reject an appeal, crush resistance

- $\quad \mathrm{L} 3=$ (adjective + noun) or (noun used in an attributive way + noun) e.g. strong tea, a crushing defeat, house arrest, land reform

- $\quad \mathrm{L} 4=$ noun + verb naming the activity which is performed by a designate of this noun e.g. bombs explode, bees sting

- $\quad \mathrm{L} 5=$ quantifier + noun e.g. $a$ swarm of bees, a piece of advice

- $\quad \mathrm{L} 6=\mathrm{adverb}+$ adjective e.g. hopelessly addicted, sound asleep

- $\quad \mathrm{L7}=$ verb + adverb e.g. argue heatedly, apologize humbly

\subsection{The importance of the proper use of collocations for English lan- guage students}

English language students, more often than not, face difficulties while acquiring collocations due to several reasons: the fact that they are mostly taught grammar rules, negative transfer of L1 (collocates of a certain word in one language - language A, may not be used for the same translation equivalent in the other language - language $B$ ) and their unawareness of the importance of collocations in the process of language learning (Begagić \& Dubravac, 2014).

The immense influence of the mother tongue on speaking or writing in the second language and the influence of the second language on the mother tongue when doing translations should also be mentioned. This is evident in the example provided by Riđanović (2007), regarding a statement a foreign politician made in an interview for the local newspapers. The statement (in the BCS language):

(3) *Snažno se ne slažem sa Terzićevim potezom.

This statement sounds odd and seems incorrect to the native speaker of the BCS language. What happened here was that the interview was conducted in English because the politician who made the statement is a native speaker of English, but

\footnotetext{
${ }^{2}$ For a complete list of 19 different patterns see Benson, Benson and Ilson (1986).
} 
the translator made an error translating the statement word for word, without paying attention to the collocational differences between the two languages. The English original probably sounded like this:

(4) I strongly disagree with Terzić's move,

which is a natural-sounding, grammatically and semantically correct sentence in English. Riđanović (2007) says that this type of error could not be made by the person familiar with modern linguistics because such a person is aware of the presence of collocations in language as well as the fact that collocations are different from language to language. Therefore, the focus of their attention would automatically be the recognition of the collocations in the source-language and finding suitable translation equivalents in the target-language. This suggests that learners' awareness of the importance of collocations, as well as the problems they might encounter must be raised from the early beginnings of language learning.

Many researchers suggest that unlike native speakers, English language students hardly use prefabricated units in language production:

In building his utterances, he (the native speaker) makes use of large prefabricated sections. The learner, on the other hand, having automated few collocations, continually has to create structures that he can only hope will be acceptable to native speakers (...). His building material is individual bricks rather than prefabricated sections. (Kjellmer 1991: 124)

This is probably due to the fact that students are encouraged to think of grammar as the bones of the language and vocabulary as the flesh - and knowing the grammar and vocabulary, you have the whole skeleton - you 'know' the language. This is an outdated principle now, because the current view is that the language consists largely of prefabricated 'chunks' of lexis - collocations (Cowie, 1994; Hill, 1999; Riđanović, 2007; Islam, 2006).

Native speakers produce language easily and with a greater speed than language learners, because they are calling on a vast repertoire of ready-made language in their mental lexicons. This works for their reading and listening comprehension, too. The main difference between native speakers and non-native speakers is that native speakers have met more examples of language and this fact enables them to process and produce language at a much faster rate than the average student (Hill, 1999). This suggests that learning to say something the way native speakers do is essential to fluency. It is easier to recall 'chunks' of language from your memory, than to actually create 'chunks' yourself - it takes less time, and the chance that a collocational error will occur is diminished.

Most collocational errors occur because unacceptable items are created rather than misunderstood. Non-native speakers, when faced with what is a new collocation to them, are able to derive and process its meaning correctly. On the other hand, when they have to express a certain concept, they are most likely going to 
use sequences that are not acceptable in second language. ${ }^{3}$ Therefore, it can be stated that collocation is the key to fluency.

A new concept of collocational competence should be introduced as it is very important for the English language students. According to Hill (1999) any analysis of students' speech or writing shows that this lack of collocational competence is one of the most obvious weaknesses. He states that students with good ideas often lose marks because they do not know the four or five most important collocates of a key word that is central to what they are writing about. When students do not know the collocations which express precisely what they want to say, they create longer utterances which increase the likelihood of further errors. With regard to the above mentioned, it can be stated that learning collocations will give students alternative ways of saying something, and considerably improve their language performance.

\section{Methodology}

\subsection{The Present Study}

The present study examines the productive and receptive knowledge of lexical collocations amongst the students of English language and literature whose native language is the BCS language. It examines the possible differences in collocational competence between first and fourth year students, as well as the difference between participants' performance on three types of collocations: verb + noun, adjective + noun, and verb + adverb.

This study addresses the following research questions:

1. Is there a significant difference in the collocational competence between first and fourth year students?

2. Is there a significant difference between the participants' knowledge of productive and receptive collocations?

3. Which type of collocation, among the selected ones, was the most difficult for the participants - is there a difference between first and fourth year students?

\footnotetext{
${ }^{3}$ Although there is a general agreement on the fact that the production of correct collocations is more problematic than their comprehension, some studies stress the importance of comprehension of prefabricated expressions, and consequently of collocations, for the correct processing of a message (Cowie and Howarth, 1996; Hunston and Francis 2000).
} 


\subsection{The choice of the examined collocations}

Collocations that are examined in this study belong to the group of lexical collocations, and more specifically, three types of lexical collocations are chosen: verb + noun, adjective + noun, and verb + adverb. These collocations are chosen because some of the earlier studies have shown that lexical collocations are easier to acquire than grammatical collocations, and the chance that students being tested in this study are more familiar with these types of collocations, as opposed to other types, is higher. This diminishes the risk of students guessing the collocation, which apart from improving the chances for answering the research questions more accurately, also increases the reliability of the data collected from this study.

\subsection{Participants}

Participants in this study are 40 students at the Department of English language and literature in Zenica. The first group consists of 20 first year students at the beginning of their studies, and the second group consists of 20 fourth year students in their last semester of studies. At the moment of testing, the first group had been learning English for 9 years, and the second group for 12 years. Since all of the participants are students at the Department of English Language and Literature, their English levels are at upper-intermediate or advanced level.

\section{Research}

The data-gathering part of the study consisted of two parts: three gap-filling productive tests and an appropriateness of judgment receptive test. The three gapfilling tests were designed to measure the participants' productive collocational proficiency. The tests included 60 target collocations that examined three types of lexical collocations: 20 verb + noun collocations, 20 adjective + noun collocations and 20 verb + adverb collocations. The three tests were used in restrictive structures, and only one correct answer was allowed. The initial letters of the target collocations were provided as a clue. This was done to prevent guessing, and to ensure that the participants selected only the target word. 4

The appropriate judgment test was designed to measure the participants' receptive competence in identifying the correct English collocations. The test consisted of 72 items - the 60 target collocations used in the three gap-filling-tests were included, along with 12 mismatched collocations that acted as distractors. The participants were asked to judge whether the underlined part of a sentence was accepta-

\footnotetext{
${ }^{4}$ See Appendix I.
} 
ble or not by circling a number corresponding to the inappropriate part of the sentence. ${ }^{5}$

The purpose of the study is to assess the performance of the BCS native speakers, students of English language and literature, on tests evaluating their use of English collocational knowledge. The results reported below show differences between all participants' scores in all test sections (productive verb + noun, productive adjective + noun, productive verb + adverb, and receptive collocations) and provide answers to the research questions.

\subsection{The Results and the interpretations of findings}

\subsubsection{Collocational knowledge of first and fourth year students}

The first research question that needed to be answered in this study is whether a significant difference between collocational competence of first and fourth year students exists. To answer this question the total number of correct answers for each collocation in the productive and the receptive tests are compared between the two groups. The results presented in Table 1 show the total number of correctly produced and recognized collocations by the participants and the total number of possible correct collocations. The table indicates that fourth year students performed significantly better on both tests, productive and receptive.

Table 1. Correct collocations produced by students and the total number of possible correct collocations.

\begin{tabular}{lccc}
\hline & $\begin{array}{c}\text { First year } \\
\text { students }\end{array}$ & $\begin{array}{c}\text { Fourth year } \\
\text { students }\end{array}$ & $\begin{array}{c}\text { Total number of possi- } \\
\text { ble correct collocations }\end{array}$ \\
\hline $\begin{array}{l}\text { Productive test } \\
\text { (correct collocations) }\end{array}$ & 93 & 252 & 1200 \\
$\begin{array}{l}\text { Receptive test } \\
\text { (correct collocations) }\end{array}$ & 834 & 1059 & 1200 \\
\hline
\end{tabular}

The results suggest that there is a significant difference in the collocational knowledge between first and fourth year students, which becomes obvious when data from the table is converted into percentages, and presented in Chart 1 and Chart 2.

\footnotetext{
${ }^{5}$ See Appendix II.
} 

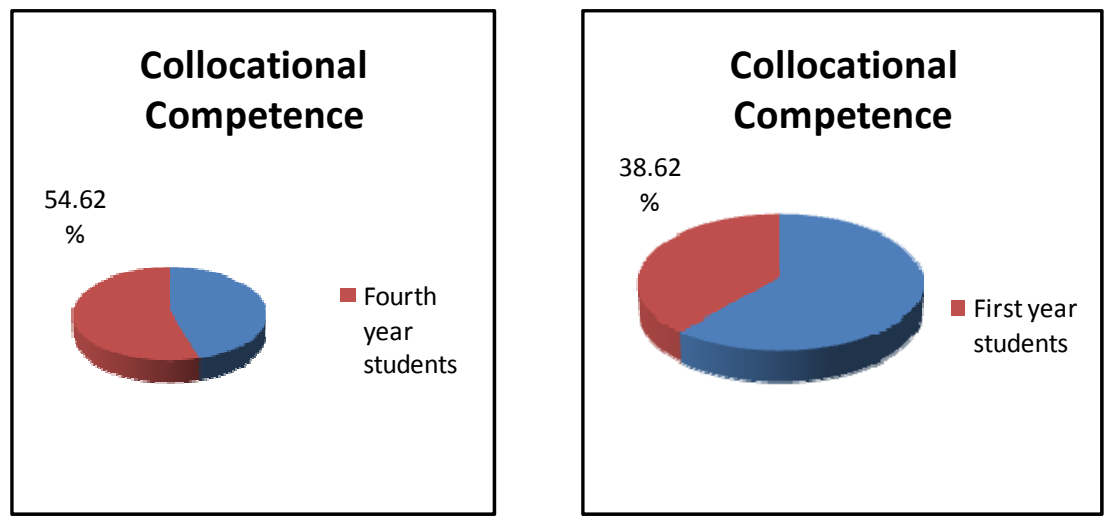

Figures 1-2. Fourth and first year students' collocational competence.

The fact that fourth year students showed more advanced collocational competence than first year students suggests that educational environment plays an important role during the process of learning collocations. Senior students have been more exposed to collocations - through lectures (most lectures are held in English) and exercises on the one hand, and through literature they had to read for the classes on the other hand.

Overall, the results of the collocational competence for both first and fourth year students are unsatisfactory, and indicate poor students' collocational knowledge in general.

\subsubsection{The productive and receptive knowledge of collocations}

The issue of the difference between the participants' productive and receptive knowledge of collocations is the second aspect of this study. The results indicate that collocational mismatches were frequent in participants' answers, both productively and receptively, and that there is a significant difference between the participants' productive and receptive knowledge of collocations. The participants' productive knowledge of collocations lagged behind and did not develop as their receptive knowledge, as can be seen in Table 1 . It is important to mention that senior students performed better on both, productive and receptive tests.

Senior students managed to correctly produce $21 \%$ of the examined collocations, while first year students produced only 7.75\%. Participants performed much better on the appropriate judgment test, which measured the participants' receptive competence. First year students managed to identify $69.5 \%$ of the correct collocations, while senior students did a lot better, and managed to identify $88.25 \%$. 
Overall results of productive and receptive tests for both groups of students, are presented in Chart 3 (for productive knowledge of collocations) and in Chart 4 (for receptive knowledge of collocations).
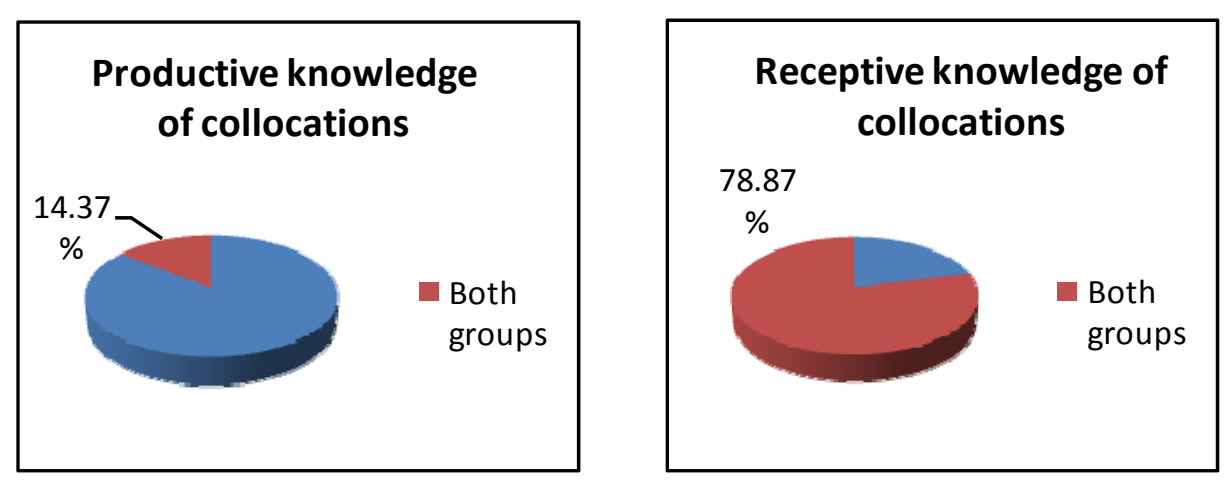

Figures 3-4. Percentage of the productive and the receptive knowledge for both groups.

These results are not surprising due to the fact that teaching collocations is often neglected. Teachers are more focused on giving students synonyms rather than providing them with the appropriate collocations to be used in certain contexts. This is the reason why students are often unable to use the words in the correct contexts, which can lead to misunderstanding. It is not surprising that participants' receptive knowledge is much better than their productive knowledge, because evidence suggests that receptive typically precedes productive knowledge.

\subsubsection{Collocation types}

This study also explores the differences between participants' productive scores on three categories of collocations: verb + noun, adjective + noun and verb + adverb. The purpose was to identify which type of the above mentioned collocations is the most difficult to acquire, and to see whether the results would be the same for first and fourth year students. Detailed scores are presented in Table 2 (for first year students), and in Table 3 (for fourth year students). 
Table 2. Collocation types' scores on productive tests for first year students.

\begin{tabular}{lccc}
\hline $\begin{array}{c}\text { Types of colloca- } \\
\text { tions }\end{array}$ & $\begin{array}{c}\text { The number of correct- } \\
\text { ly produced colloca- } \\
\text { tions }\end{array}$ & $\begin{array}{c}\text { Total number of } \\
\text { possible colloca- } \\
\text { tions }\end{array}$ & Percentage \\
\hline verb + noun & 57 & 400 & $14.25 \%$ \\
adjective + noun & 31 & 400 & $7.75 \%$ \\
verb + adverb & 5 & 400 & $1.25 \%$ \\
\hline
\end{tabular}

Table 2 shows that first year students performed best on verb + noun collocation test. They managed to produce more correct verb + noun collocations $(6,5 \%$ more than adjective + noun collocations, and 13\% more than verb + adverb collocations). This indicates that the most difficult type of collocation to acquire for freshmen students is the verb + adverb type of collocation, and that the easiest type to acquire is the verb + noun.

Table 3. Collocation types' scores on productive tests for fourth year students.

\begin{tabular}{lccc}
\hline $\begin{array}{c}\text { Types of colloca- } \\
\text { tions }\end{array}$ & $\begin{array}{c}\text { The number of correct- } \\
\text { ly produced colloca- } \\
\text { tions }\end{array}$ & $\begin{array}{c}\text { Total number of } \\
\text { possible colloca- } \\
\text { tions }\end{array}$ & Percentage \\
\hline verb + noun & 130 & 400 & $32,5 \%$ \\
adjective + noun & 83 & 400 & $20,75 \%$ \\
verb + adverb & 39 & 400 & $9,75 \%$ \\
\hline
\end{tabular}

Table 3 indicates that senior students performed best on verb + noun collocation test as well, producing more correct verb + noun collocations $(11.75 \%$ more than adjective + noun collocations, and $22.75 \%$ more than verb + adverb collocations). This suggests that verb + adverb type of collocation is the most difficult to acquire for both first and fourth year students, and that verb + noun type of collocations is the easiest type to acquire. Therefore, there is no difference between first and fourth year students concerning difficulties in acquiring certain type of collocations.

The overall results regarding the production of the three types of tested collocation are presented in Charts 5, 6, and 7 for verb + noun, adjective + noun and verb + adverb collocations respectively. The Charts demonstrate very poor productive performance on adjective + noun and verb + adverb collocation tests, and somewhat better productive performance on verb + noun collocation test. 

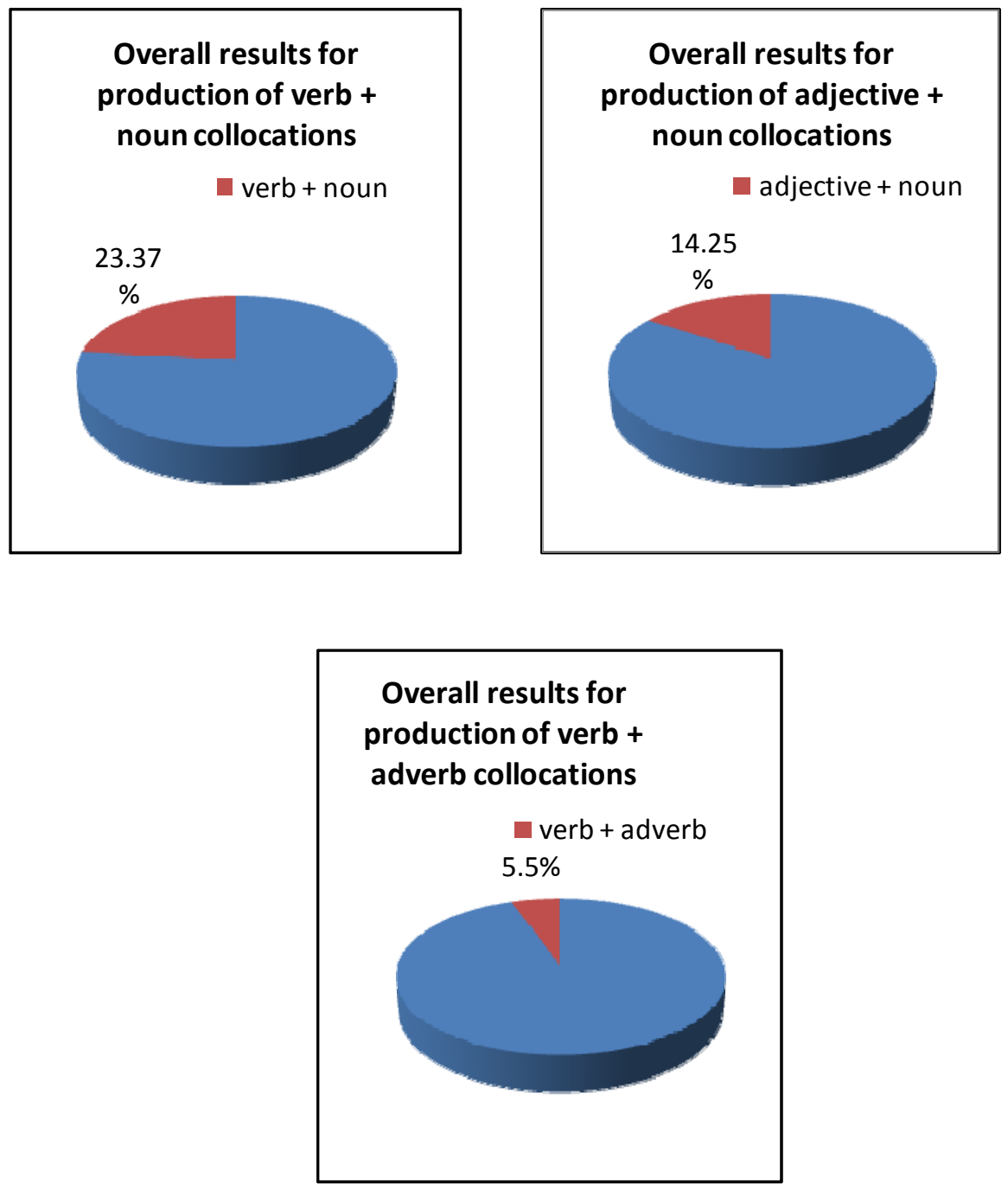

Figure 5. Verb + noun collocations; Figure 6. Adjective + noun collocations; Figure 7. Adverb + noun collocations.

The most probable reason why students find the production of verb + adverb collocations most difficult could be the influence of their mother tongue on the production of L2 (adverbs in the BCS language differ significantly from adverbs in the English language). Another reason could be that, generally, in classrooms, the emphasis is put on verbs rather than on adjectives or adverbs. 


\section{Conclusion}

The present study examines the productive and receptive knowledge of lexical collocations but also emphasizes the importance of the proper use of collocations for the English language students. The results suggest that English language students at the Department for English language and literature at the University of Zenica have difficulties producing collocations due to several reasons: the fact that they are mostly taught grammar rules, negative transfer of L1 (collocates of a certain word in one language - language A, may not be used for the same translation equivalent in the other language - language B), the fact that teaching collocations is often neglected, but also because of their unawareness of the importance of collocations in the process of language learning.

Although the results indicate poor students' collocational knowledge in general, both first and fourth year students demonstrated greater knowledge of receptive than of productive collocations. Moreover, the results reveal that fourth year students show more advanced collocational competence than first year students, and that verb + adverb collocation type is the most difficult to acquire for both groups of students.

According to all aforementioned suggestions, it can be stated that more effort should be made towards developing learners' collocational competence, taking into consideration their importance in the process of language acquisition. Since collocations represent a relatively new concept in linguistics, more awareness should be raised regarding this matter and there should be a stronger emphasis on collocations in the process of curriculum development.

\section{References}

Aghbar, Ali-Asghar (1990). Fixed expressions in written texts: Implication for assessing writing sophistication. Paper presented at a meeting of the English Association of Pennsylvania State System Universities, October 1990.

Bäcklund, Ulf (1973). The Collocations of Adverbs of Degree in English. Studia Anglistica Upsaliensia 13. Uppsala: University of Uppsala

Bäcklund, Ulf (1976). Frozen adjective-noun collocations in English. Cahiers de Lexicologie 28.1: 74-88.

Bahns, Jens, \& Moira Eldaw (1993). Should we teach EFL students collocations? System 21(1): 101-114.

Begagić, Mirna, \& Vildana, Dubravac (2014). Foreign language learners' collocational competence. Paper presented at the $5^{\text {th }}$ International Conference, Cultural Identity in Digital Era, Faculty of Philosophy, University of Zenica, Zenica

Benson, Morton, Evelyn Benson, \& Robert Ilson (1986). The BBI Combinatory Dictionary of English. Johns Benjamins Publishing Company: Amsterdam

Cowie, Anthony P. (1994). Phraseology. Asher, Ronald, eds. The Encyclopedia of Language and Linguistics. Oxford: Pergamon, 3168-3171. 
Cowie, Anthony, \& Peter, Howarth (1996). Phraseological competence and written proficiency. Blue, George, ed. Language and Education. Clevedon: Multilingual Matters, 80-93.

Cruse, Alan (1986). Lexical Semantics. Cambridge: Cambridge University Press.

Crystal, David (1985). A dictionary of Linguistics and Phonetics. Oxford: Basil Blackwell Ltd.

Fayez-Husein, Riyad (1990). Collocations: The missing link in vocabulary acquisition amongst EFL learners. Fisiak, Jacek, eds. Papers and Studies in Contrastive Linguistics: The Polish Linguistics Contrastive Project, 26. Poznan: Adam Mickiewicz University, 123-136.

Firth, John (1957). Papers in Linguistics 1934-1951. London: Oxford University Press

Halliday, Michael, Angus McIntosh, \& Peter Strevens (1964). The Linguistic Sciences and Language Teaching. London: Longman.

Hill, Jimmie (1999). Collocational competence. English Teaching Professional 11: 3-6.

Hunston, Susan, \& Francis Gill (2000). Pattern Grammar: A Corpus-Driven Approach to the Lexical Grammar of English. Amsterdam: John Benjamins.

Islam, Carlos (2006). Lexical approach: What does the lexical approach look like? Retrieved February 18, 2014 www.teachingenglish.org.uk/think/methodology/lexical_ approach1.shtml.

Kjellmer, Göran (1991). A mint of phrases. In Aijmer, Karin, Bengt Altenberg (eds.), English Corpus Linguistics. Studies in Honour of Jan Svartvik (pp. 111-127). London, New York: Longman.

Nasselhauf, Nadja (2005). Collocations in a Learner Corpus. Amsterdam \& Philadelphia: John Benjamins.

Ozaki, Shigeru (2011). Teaching collocations effectively with the aid of L1. The Language Teacher 35.3: 37-40.

Ridout, Ronald, \& David Waldo-Clarke (1970). A reference Book of English. London: Macmillan.

Riđanović, Midhat (2007). Praktična engleska gramatika : uz poređenja s našim jezikom, 2. dopunjeno izd. Sarajevo: Šahinpašić

Seaton, Brian (1982). A Handbook of English Language Teaching Terms and Practice. London: The Macmillan Press.

Sinclair, John (1991). Corpus, Concordance, Collocation. Oxford: Oxford University Press.

Stubbs, Michael (2002). Words and Phrases: Corpus Studies of Lexical Semantics. OxfordMalden, MA: Blackwell.

Wray, Alison (2002). Formulaic Language and the Lexicon. Cambridge: Cambridge University Press.

Zhang, Xiong (1993). English Collocations and Their Effect on the Writing of Native and Nonnative College Freshmen. Unpublished PhD thesis, Indiana: University of Pennsylvania.

Received March 23, 2014

Accepted for publication September 18, 2014 
Author's address:

Mirna Begagić

University of Zenica

Faculty of Philosophy

Zmaja od Bosne 56

72000 Zenica, Bosnia and Herzegovina

mjasavic@yahoo.de 


\section{Appendix I: Fill-In-The-Blank Test}

\section{You have 25 minutes to complete this test. Please respond to the following:}

Part1:

Put the verb which best completes the sentence in the blank. Spelling and grammar are not counted, only your choice of words. Use the first letter as a clue.

1. The manager $\underline{\mathrm{d}}$ ability to produce effective results in diverse and challenging environments.

2. Nation looks back on 50 years of Civil rights history with President Obama and others d speeches to commemorate the historic 1963 march on Washington.

3. Cats $\underline{\mathrm{d}}$ affection differently and in a more subtle way than dogs.

4. What $\underline{a}$ the interest of students was the fact that lectures were held outdoors.

5. Nurses and phlebotomists $\underline{\mathrm{d}}$ blood to perform a variety of medical tests.

6. The jogger stopped to $\underline{C}$ her breath and regain her strength.

7. Mr. Biden promised he would not let the middle class $\underline{\mathrm{c}}$ the burden of economic reforms.

8. There are many ways to $\underline{a}$ citizenship once you enter the country.

9. He r consciousness in hospital after being in a coma for 4 months.

10. Studies show that rising seas will $\underline{i}$ serious damage along U.S. West Coast.

11. Researchers announced that they $\underline{m}$ a discovery of a new species of mammal called olinguito.

12. Many mountaineers are training hard in order to a the feat of climbing Mount Everest.

13. All experts have advised that $\underline{b}$ the gap between IT and business sectors should be a high priority for any company.

14. Nuclear Fusion at a star's core g the star's surface and is then radiated into space.

15. Most famous comedians made their careers by $\underline{\mathrm{d}}$ the heat that eventually makes its way to 16. While some revolutionaries seek to a imitations of celebrities. redistribute power. independence, others aim only to

17. Psychology g us insight into what is going on inside people's minds.

18. In our daily lives, when we are faced with a problem or a situation which requires a decision, we are often reminded to $\underline{\text { a }}$ logic and reasoning for the most desired results.

19. To avoid getting lost in the forest you should $\mathrm{f}$ the path, and avoid diverting from it.

20. There are new evidence which suggest that the Congressman a his position for personal gain. 


\section{Part 2:}

Put the adjective which best completes the sentence in the blank. Spelling and grammar are not counted, only your choice of words. Use the first letter as a clue.

1. D abuse is the use of illicit drugs, or the abuse of prescription or over-the-counter drugs.

2. Since its publication last year, Dr Fitzpatrick's book has received $\underline{\mathbf{c}}$ acclaim from a number of highly regarded organizations.

3. Physical activity helps children feel good and promotes a $\underline{\mathbf{h}}$ appetite.

4. It is a fact that from conception both a physical and an $\underline{\mathrm{e}}$ bond are created between mother and child.

5. India is trying to have "more understanding" with China, while at the same time strengthening its capabilities along the $\underline{\mathrm{d}}$ border with its neighbor, Defense Minister AK Antony said on Monday.

6. A day of fun at the Telegraph Tomorrow Car Cruise turned into a night of $\underline{u}$ chaos before police closed down parking lots of spectators and shut down Telegraph Road.

7. Unsurprisingly it appears, the more successful the game, the longer it takes for the $\mathbf{g}$ decline in price to take effect.

8. Nick Griffin has suffered a c defeat in his attempt to become the British National Party's first MP.

9. Duchene arrived at the jewelers in El Paso, Texas, in her wheelchair, pushed by her partner in crime, before jumping out and putting on her $\underline{\mathrm{c}}$ with two eye holes. disguise - a black bin bag

10. A good democrat may disagree with the laws of his country but will never carry that disagreement to $\underline{\mathbf{o}}$ disobedience.

11. Europe and Asia, which in the past experienced $\underline{s}$ famines, sometimes with deaths in the hundreds of thousands or millions, have now largely eliminated famines through social and technological change.

12. Bulgaria's prosecuting authority has confirmed that 1 fraud was committed in the energy sector.

13. The bishops expressed $\underline{\mathrm{d}}$ gratitude to those who showed their concern in a respectful way.

14. In this case, the final duty of the Public Guardian and Trustee is to distribute the net estate to the 1 heirs under the law of Ontario.

15. Producing or using $\underline{\mathrm{C}}$ money is a form of fraud or forgery.

16. The first chapter on dark matter and dark energy was indeed a $\underline{\mathbf{b}}$ mystery of science.

17. Authorities say the best way to avoid infection is frequent hand washing and avoiding foods of $\mathbf{d}$ origin or preparation.

18. A $\underline{b}$ passion for fly-fishing is what all competitors have in common.

19. Their history, stadium and fans make them an a proposition for any wealthy businessman looking to take on a club. 
20. It is $\underline{\mathbf{s}}$ stupidity to drive in the rain at 150 plus miles an hour on a windy course, no matter how good the driver, car and tires are.

Part 3:

Put the adverb which best completes the sentence in the blank. Spelling and grammar are not counted, only your choice of words.

1. The results will be a cue for whether we will get a new government that will act d__ on economic front, Mr Jaipuria added.

2. Soybean maturity has advanced $\underline{r}$ in Minnesota in the last week, but soybean maturity still lags behind the normal pace.

3. Cellular operators have $\underline{r}$ agreed to install the biometric verification solution for verifying users data.

4. The office manager and Dr. G called Mr. M and apologized p for the mix-up.

5. Mr. Bond says that he $\underline{\mathrm{i}}$ appreciates your work, and that he would like to collaborate with you in the future.

6. American troops were attacked $\mathrm{v}$ during the military exercise in Islamabad.

7. Ayatollah Khomeini, the father of the current theocratic government, $\underline{f}$ believed that Zionism was a Western imperialist project fracturing the Muslim world and that it was Iran's responsibility to eliminate it.

8. Serious injuries don't always bleed $\underline{\mathrm{h}}$ and some relatively minor injuries can bleed quite a lot.

9. With South Korea's foreign-exchange reserves having climbed $\underline{\mathrm{s}}$ since 2011 and hitting three successive records since July, some are wondering whether the brakes can be put on all this saving.

10. Christians and Muslims have co-existed $\mathrm{p}$ in Palestine for centuries.

11. After each losing day Jimmy Spithill would $\underline{\mathbf{b}}$ declare: 'We can win races'.

12. Salami and his boss Jafari and the other IRGC generals know better than o defy the wishes of Khamenei.

13. The claims $\underline{\mathrm{c}}$ imply that Nintendo's next-generation system is on the horizon and that it needs to take some actions to ensure its popularity among developers.

14. Nearly half of all adults with high blood pressure are women; after menopause, the chances of developing the condition increase $\underline{c}$

15. Protesters $\underline{b}$ interrupted the French Open final Sunday between Rafael Nadal and David Ferrer, with one man jumping onto the court with a fiery flare spurting white smoke.

16. I heard someone $\mathrm{g}$ knocking on the door, so I went downstairs to see who it is.

17. He was listening a to a senior colleague. 
18. Milgram reported an astonishing $65 \%$ of subjects $\underline{b}$ obeyed orders to administer increasing electrical shocks to a subject they could not see but heard as the shocks became more intense.

19. "We c reject the Venezuelan government's allegations of U.S. government involvement in any type of conspiracy to destabilize the Venezuelan government," she told reporters Tuesday.

20. For the Guardian he reported e on the mid-1990s war in Bosnia, particularly on the concentration camps in northwest Bosnia. 


\section{Appendix II: Acceptability Judgment Test}

Decide whether the underlined part of the sentence is acceptable or not. Circle the number corresponding to the strange part of the sentence. You have 25 minutes.

1. After arguing continually for two months, they decided to discuss softly about the matters that bother them.

2. He was listening attentively to a senior colleague.

3. The claims clearly imply that Nintendo's next-generation system is on the horizon and that it needs to take some actions to ensure its popularity among developers.

4. The forecaster predicted hard rain and strong winds during the afternoon storm.

5 . The results will be a cue for whether we will get a new government that will act decisively on economic front, Mr Jaipuria added.

6. Nuclear Fusion at a star's core generates the heat that eventually makes its way to the star's surface and is then radiated into space.

7. To avoid getting lost in the forest you should follow the path, and avoid diverting from it.

8. Unsurprisingly it appears, the more successful the game, the longer it takes for the gradual decline in price to take effect.

9. They argued so heavily, even the neighbors three stories up could hear them.

10. The manager demonstrates ability to produce effective results in diverse and challenging environments.

11. Psychology gives us insight into what is going on inside people's minds.

12. Drug abuse is the use of illicit drugs, or the abuse of prescription or over-the-counter drugs.

13. Duchene arrived at the jewelers in El Paso, Texas, in her wheelchair, pushed by her partner in crime, before jumping out and putting on her cunning disguise - a black bin bag with two eye holes.

14. Nearly half of all adults with high blood pressure are women; after menopause, the chances of developing the condition increase considerably.

15. Nation looks back on 50 years of Civil rights history with President Obama and others deliver speeches to commemorate the historic 1963 march on Washington.

16. In our daily lives, when we are faced with a problem or a situation which requires a decision, we are often reminded to apply logic and reasoning for the most desired results.

17. A good democrat may disagree with the laws of his country but will never carry that disagreement to open disobedience.

18. In this case, the final duty of the Public Guardian and Trustee is to distribute the net estate to the lawful heirs under the law of Ontario.

19. "We completely reject the Venezuelan government's allegations of U.S. government involvement in any type of conspiracy to destabilize the Venezuelan government," she told reporters Tuesday. 
20. Ayatollah Khomeini, the father of the current theocratic government, firmly believed that Zionism was a Western imperialist project fracturing the Muslim world and that it was Iran's responsibility to eliminate it.

21. He recovered consciousness in hospital after being in a coma for 4 months.

22. Authorities say the best way to avoid infection is frequent hand washing and avoiding foods of dubious origin or preparation.

23. Coca-Cola mainly produces tender drinks, rather than alcoholic ones.

24. Mr. Bond says that he immensely appreciates your work, and that he would like to collaborate with you in the future.

25. Physical activity helps children feel good and promotes a healthy appetite.

26. Cats display affection differently and in a more subtle way than dogs.

27. Most famous comedians made their careers by doing imitations of celebrities.

28. Nick Griffin has suffered a crushing defeat in his attempt to become the British National Party's first MP.

29. This book describes ten ways to use advantage of the web.

30. For the Guardian he reported extensively on the mid-1990s war in Bosnia, particularly on the concentration camps in northwest Bosnia.

31. Christians and Muslims have co-existed peacefully in Palestine for centuries.

32. A burning passion for fly-fishing is what all competitors have in common.

33. Europe and Asia, which in the past experienced severe famines, sometimes with deaths in the hundreds of thousands or millions, have now largely eliminated famines through social and technological change.

34. The jogger stopped to catch her breath and regain her strength.

35. Many mountaineers are training hard in order to accomplish the feat of climbing Mount Everest.

36. A day of fun at the Telegraph Tomorrow Car Cruise turned into a night of utter chaos before police closed down parking lots of spectators and shut down Telegraph Road.

37. The bishops expressed deep gratitude to those who showed their concern in a respectful way.

38. He implied visibly that he thinks I don't deserve to be here.

39. Milgram reported an astonishing $65 \%$ of subjects blindly obeyed orders to administer increasing electrical shocks to a subject they could not see but heard as the shocks became more intense.

40. What aroused the interest of students was the fact that lectures were held outdoors.

41. Since its publication last year, Dr Fitzpatrick's book has received critical acclaim from a number of highly regarded organizations.

42. It is sheer stupidity to drive in the rain at 150 plus miles an hour on a windy course, no matter how good the driver, car and tires are.

43. Protesters briefly interrupted the French Open final Sunday between Rafael Nadal and David Ferrer, with one man jumping onto the court with a fiery flare spurting white smoke.

44. The most dominant political groups in the US are the Decomcratic and the Republican. 
45. Salami and his boss Jafari and the other IRGC generals know better than openly defy the wishes of Khamenei.

46. Studies show that rising seas will inflict serious damage along U.S. West Coast.

47. While some revolutionaries seek to achieve independence, others aim only to redistribute power.

48. Their history, stadium and fans make them an attractive proposition for any wealthy businessman looking to take on a club.

49. With South Korea's foreign-exchange reserves having climbed steadily since 2011 and hitting three successive records since July, some are wondering whether the brakes can be put on all this saving.

50. He apologized modestly and promised to never do it again.

51. I heard someone gently knocking on the door, so I went downstairs to see who it is.

52. Soybean maturity has advanced rapidly in Minnesota in the last week, but soybean maturity still lags behind the normal pace.

53. Nurses and phlebotomists draw blood to perform a variety of medical tests.

54. It is a fact that from conception both a physical and an emotional bond are created between mother and child.

55. India is trying to have "more understanding" with China, while at the same time strengthening its capabilities along the disputed border with its neighbor, Defense Minister AK Antony said on Monday.

56. The boxer gave him a blue eye, so he was taken to hospital.

57. Serious injuries don't always bleed heavily, and some relatively minor injuries can bleed quite a lot.

58. Producing or using counterfeit money is a form of fraud or forgery.

59. Mr. Biden promised he would not let the middle class carry the burden of economic reforms.

60. All experts have advised that bridging the gap between IT and business sectors should be a high priority for any company.

61. Cellular operators have reluctantly agreed to install the biometric verification solution for verifying users data.

62. Inborn abilities always make an effect on what we become.

63. After each losing day Jimmy Spithill would boldly declare: 'We can win races'.

64. There are new evidence which suggest that the Congressman abused his position for personal gain.

65. Researchers announced that they made a discovery of a new species of mammal called olinguito.

66. Bulgaria's prosecuting authority has confirmed that large-scale fraud was committed in the energy sector.

67. Could you take an eye on my bag while I go to the toilet?

68. American troops were attacked vigorously during the military exercise in Islamabad. 
69. The first chapter on dark matter and dark energy was indeed a baffling mystery of science.

70. There are many ways to acquire citizenship once you enter the country.

71. The office manager and Dr. G called Mr. M and apologized profusely for the mix-up.

72. He had a close escape from gunfire. 